\title{
th. 1679
}

LA-8297-PR

Progress Report
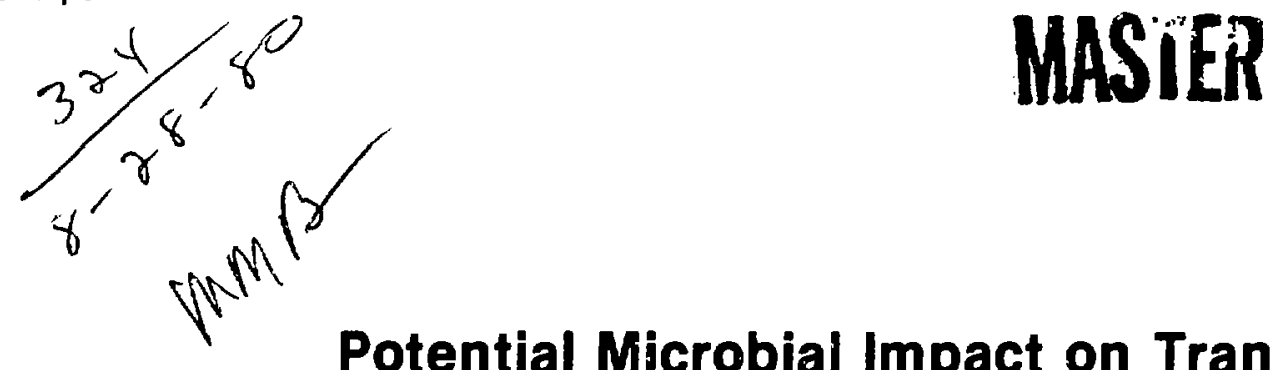

Potential Microbial Impact on Transuranic Wastes Under Conditions Expected in the Waste Isolation Pilot Plant (WIPP) Annual Report October 1, 1978-September 30, 1979 
LA.8297-PR

Progress Report

UC-70

Issued: July 1980

\title{
Potential Microbial Impact on Transuranic Wastes Under Conditions Expected in the Waste Isolation Pilot Plant (WIPP)
}

\section{Annual Report}

October 1, 1978-September 30, 1979

\author{
Benjamin J. Barnhart \\ Evelyn W. Campbell \\ Eleuterio Martinez \\ Douglas E. Caldwell* \\ Richard Hallett**
}
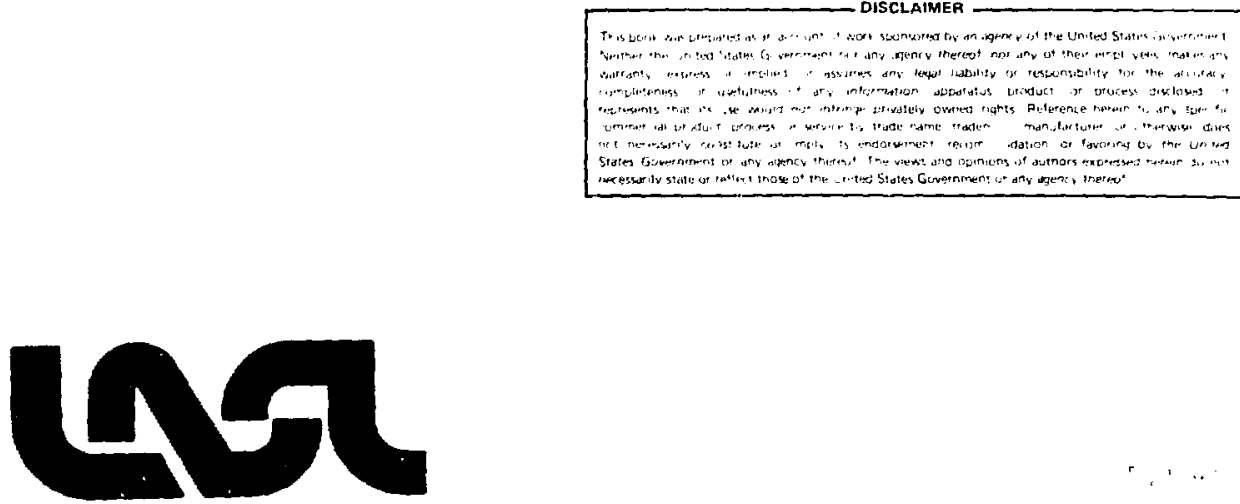


\section{CONTWNTS}

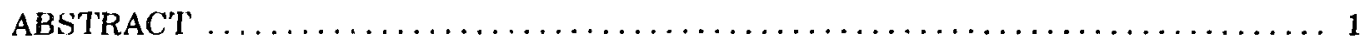

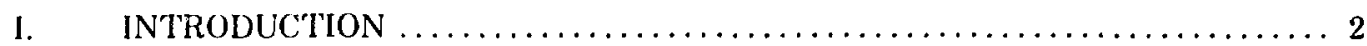

I1. ASSESSMENT OF MICROFLORA IN LASL TRU BURIAL SITE

SOIL AND IN TRU WASTE FROM STEEL DRUMS (LASL) $\ldots \ldots \ldots \ldots \ldots \ldots 2$

III. RADIOBIOLOGY OF LASL TRU WASTE (LASL) $\quad \ldots \ldots \ldots \ldots \ldots \ldots \ldots \ldots 7$

iv. PO'TENTIAL ALKYLATION OF TKU ELEMENTS (LASL) $\ldots \ldots \ldots \ldots \ldots \ldots 7$

V. SOLUBIIIZATION OF PLUTONIUM BY A CHELATE

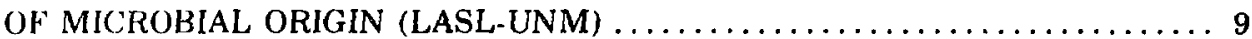

VI. CARBON DIOXIDE GAS GENERATION STUDIES (UNM) $\ldots \ldots \ldots \ldots \ldots \ldots 11$

VII. CHELATE DEGRADATION STUDIES (UNM) $\ldots \ldots \ldots \ldots \ldots \ldots \ldots \ldots \ldots \ldots$

VIII. IDENIIFICA'TION AND ENUMERATION OF MAJOR GROUPS

OF MICROORGANISMS IN WIPP SALT BEDS (UNM) $\ldots \ldots \ldots \ldots \ldots \ldots \ldots 15$

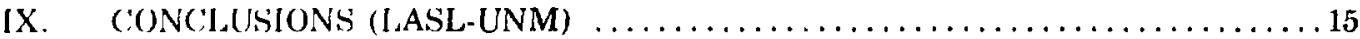

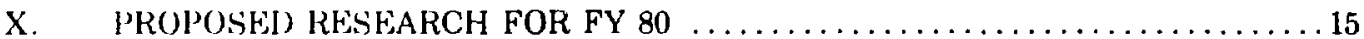

XI. MILESTONES FOR 'THE MICROBIOLOGICAL STUDIES

(WIPI' R\&D PROGRAM) BY QUARTERS (LASL-UNM) $\ldots \ldots \ldots \ldots \ldots \ldots \ldots 18$

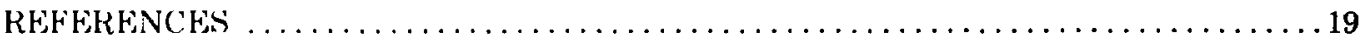




\title{
POTENTIAL MICROBIAL IMPACT ON TRANSURANIC WASTES UNDER CONDITIONS EXPECTED IN THE WASTE ISOLATIGN PILOT PLANT (WIPP)
}

\author{
Annual Report
}

October 1, 1978-September 30, 1979

by

\author{
Benjamin J. Barnhart, Evelyn W. Campbell, Eieuterio Martinez, \\ Douglas E. Caldwell, and Richard Hallett
}

\begin{abstract}
We confirmed our previous results showing elevated frequencies of radiation-resistant bacteria in microorganisms isolated from shallow transuranic (TRU) burial soil that exhibits nanocurie levels of beta and gamma radioactivity. Research to determine whether plutonium could be methylated by the microbially produced methyl donor, methylcobalamine, was terminated when literature and consulting radiochemists confirmed that other alkylated transuranic elements are extremely short-lived in the presence of oxygen. We placed greater emphasis on investigation of the dissolution of plutonium dioxide by complex formation between plutonium and a polyhydroxamate chelate simi!ar to that produced by microorganisms. New chromatographic and spectrophotometric evidence supports our previous results showing enhanced dissolution of alpha radioactivity when ${ }^{239} \mathrm{Pu}$ dioxide was mixed with the chelate Desferol. Microbial degradation studies of citrate, ethylenediamine tetraacetate (EDTA), and nitrilo triacetate (NTA) chelates of europium are in progress. Current results are summarized. All of the chelates were found to degrade. The average half-life for citrate, NTA, and EDTA was 3.2, 8.0, and 28 years, respectively.

Microbial $\mathrm{CO}_{2}$ generation is also in progress in 72 tests on several waste matrices under potential WIPP isolation conditions. The mean rate of gas generation was $5.97 \mu \mathrm{g} \mathrm{CO}_{2} / \mathrm{g}$ waste/day. Increasing temperature increased rates of microbial gas generation across treatments of brine, varying water content, nutrient additions, and anaerobic conditions. No microbial growth was detected in experiments to enumerate and identify the microorganisms in rocksalt cores from the proposed WIPP site. This report contains the yearr's research results and recommendations derived for the design of safe storaze of TRU wastes under geologic repository conditions. This was the final quarter for the LASL Life Sciences Division effort. Future LASL research for this project will be conducted by LASL's CMB Division in collaboration with the Biology Department, University of New Mexico.
\end{abstract}




\section{INTRODUCTION}

The WIPP is primarily intended for the terminal isolation of defense-related transuranic (TRU) radioactive waste. This material may include celluloses, rubbers, plastics, etc.; radionuclides including actinides; and, quite possibly, residual chelating chemicals from decontamination operations and microorganisms. The bacteria and fungi in the wastes are derived from humans who work with the materials, laboratory animals, air, and soil. Microorganisms can metabolize organic materials in radioactive waste and, as a consequence, generate significant quantities of gas. Microbial metabolites may also react with radionuclides to enhance their mobilities in solution if leaching occurs.

To quantify both the potential for microbial interactions with TRU-contaminated waste materials and the effects of such interactions on the WIPP, a research program was initiated in June 1978. This study involves the research of Douglas E. Caldwell at the University of New Mexico (UNM) Biology Department, with experimental support and additional studies at the Los Alamos Scientific Laboratory (LASL) under the direction of Benjamin J. Barnhart, Life Sciences Division. LASL participation began in August 1978 and ended September 30,1979 . These studies are important to the Sandia Laboratories' WIPP TRU waste characterization program. ${ }^{1}$

Although microbial activity in radioactive wastes has not been a prominent area of research, there ere some relevant reports. Colombo et al. ${ }^{2}$ have enumerated and classified as aerobic or anaerobic bacieria from trench water in low-level radioactive waste disposal sites at Maxey Flats, Kentucky, and West Valley, New York. $\mathrm{Au}^{3}$ and $\mathrm{Au}$ and Beckert have analyzed the microbial population in soil of the Nevada Test Site. However, the LASL-UNM project is the first to report on the numbers and partial characterizations of microorganisms extant in radioactive waste and to assess the potential microbial alteration of the chemical and physical states of transuranic elements. We have also identified the existence of radioresistant bacteria in microbial populations found in LASL low-level shallow trench burial sites.

Microbial interaction with radionuclides may cause enhanced volatilization via alkylation reactions, or in solubilization and concentration by chelation and degradation of chelates, respectively. Microbial production and degradation of chelated radionuclides, changes in radionuclide oxidation states, and alkylation reactions are also being investigated.

Microorganisms will cause production and transformation of gases within the WIPF disposal site. Carbon dioxide is the major gas expected as a result of bacterial decomposition of organic waste. The rates of $\mathrm{CO}_{2}$ production under WIPP conditions are under continuing study. In addition, other gases that may be produced and their rates of production are being identified.

This report summarizes all the pertinent data and results obtained on these microbial interaction topics.

\section{ASSESSMENT OF MICROFLORA IN LASL TRU BURIAL SITE SOIL AND IN TRU WASTE FROM STEEL DRUMS (LASI)}

\section{A. Background}

We have established standard operating procedures for enumerating microflora from LASL TRU shallow burial site TA-54, Area C, using the dilution agar-plate technique ${ }^{5}$ to estimate colony forming units (CFU)/g of soil and the most probable number (MPN) method, ${ }^{8}$ which permits estimation of population density without an actual count of single cells or colonies.

It was necessary to develop these procedures using soil not contaminated with radioactivity. ${ }^{7}$ The characterized soil was collected from just outside the fenced TRU burial site along the southern perimeter. The microbiological enumerations are reproducible and serve as a reference to compare with TRU-contaminated soil samples collected in the TA-54 area. 'These experiments have shown that it is possible to collect samples in plastic bags, freeze them in dry ice and ethanol at the collection site, and store them in a laboratory freezer without a loss in microorganisms until it is convenient to set up the cultures.

A very time-consuming effort was also made to obtain direct microbial counts in the soil using fluorescent microscopy. ${ }^{8}$ The fluorescent stain fluorescene isothiocynate (FITC) was used on soil samples immediately or after incubation to permit spore germination and formation of microcolonies. The 
stained samples were examined under a Zeiss Epifluorescence microscope using an excitation wavelength range of $450-490 \mathrm{~nm}$ and a selective FITC filter combination.

\section{B. Estimation of CFU by Dilution Agar-Plate Technique}

All manipulations were performed in a Bioquest Biological laminar flow cabinet. A 10-g aliquot of moist soil sample was transferred to an Erlenmeyer flask containing $95 \mathrm{~m} \ell$ of sterile $3 X$ distilled water or $1 \%$ peptone broth and a sterile stirring rod. The flask was placed on a magnetic stirrer for $15 \mathrm{~min}$ to disperse scil particles. Immediately, $10 \mathrm{~m} \ell$ from the suspension was diluted serially to $10^{\circ}$. A $1-\mathrm{m} \ell$ portion of each dilution was transferred to each of three petri dishes, and about $12 \mathrm{~m} \ell$ of molten agar, cooled to $42^{\circ} \mathrm{C}$, was poured into each inoculated dish. After the dishes were incubated at $28^{\circ} \mathrm{C}$ for 7 days, colonies were counted except where noted. Dishes from the dilution at which 30 to 300 colonies had developed were considered satisfactory to count.

Table I shows the results of three experiments with $10-\mathrm{g}$ aliquots of the same soil sample and growth medium used in each case.

These experiments resulted in an average of 1.94 $\times 10^{6} \mathrm{CFU} / \mathrm{g}$ of soil (incubated at $28^{\circ} \mathrm{C}$ for 7 days under aerobic conditions). The excellent agreement among experiments shows that our technique is reproducible. Either $3 \mathrm{X}$ distilled $\mathrm{H}_{2} \mathrm{O}$ or $1 \%$ peptone can be used as a diluent for misroorganisms, and numbers and types of colonies are essentially the same lising 1:10 or 1:100 trypticase soy agar (TSA).

The aneerobic cultures resulted in an average of $2.66 \times 10^{8} \mathrm{CFU} / \mathrm{g}$ of soil with good agreement between experiments. Anaerobic agar (Difco) was the medium of choice in later experiments. Except for Clostridium, colonies appearing were facultative anaerobes.

TABLE I

CFU PER GRAM OF SOIL

\begin{tabular}{l} 
Sample \\
\hline Soil collected \\
outside fenced area \\
TA-54, Area C C 2940 \\
on $10 / 20 / 78$ plated \\
immediately on \\
TSA $1: 10$
\end{tabular}

Aliquot of same sample stored 11 days in freezer, plated on 10/31/78 on TSA $1: 10$

TSA 1:100

Aliquot of same sample using $1 \%$ peptone as diluent, plated on 12/4/78 on TSA $1: 10$

TSA 1:100

Bacteria
Aerobic

Fungi

$1.33 \times 10^{6}$

$1.99 \times 10^{8}$

Mycosel

$3.6 \times 10^{3}$

at 3 days

$1.61 \times 10^{\circ}$
$1.59 \times 10^{6}$

$3.03 \times 10^{3}$

Anaerobic

Mycosel

agar (Difco)

$3.5 \times 10^{3}$

at 3 days

$2.19 \times 10^{6}$

$2.98 \times 10^{6}$
$2.97 \times 10^{3}$

Anaerobic agar (Difco)
Mycosel

$3.2 \times 10^{4}$

at 7 days 
Mycosel (fungus selection agar) in the first two experiments had to be cointed in 3 days before overgrowth made them impossible to count. In the third experiment, no colonies formed at 3 days, indicating that the agar was too hot when the plates were poured, so the result (counted at 7 days) cannot be compared with the other experiments.

\section{Estimation of Microbial Population Density by MPN}

One-m $\ell$ portions of each soil diluation were used to inoculate a series of five tubes, each containing trypticase soy broth (TSB) or thioglycollate medium. The tubes were examined microscopically for evidence of microbial growth after 7 days at $28^{\circ} \mathrm{C}$ and recorded as positive or negative. The negative dilution tubes were incubated an additional 7 days. The first experiment (October 20, 1978) showed growth in all tubes, indicating that additional dilutions must be made to find the weakest dilution at w'iich growth can be obtained. Results of the October 31,1978 experiment (tubes incubated for 14 days at $28^{\circ} \mathrm{C}$ ) are shown in Table II.

The MPN of organisms in the original sample was calculated using a factor from the table of MPN for use with 10 -fold dilutions and 5 tubes per dilution. ${ }^{6}$ The factor was multiplied by the appropriate dilution factor to obtain the MPN of the original sample.

TSB 1:10 or $1: 100$ gives the same result of $2.3 \times$ $10^{8} \mathrm{MPN}$ microorganisms/g of soil under aerobic conditions. The growth in the tubes containing Sabouraud with antibiotics may include some bacteria since the antibiotics (added to prevent bacteria from growing) are unstable with heat and on standing.

\section{Enumeration of Microflora at Various Depths in LASL TRU Burial Site Soil}

Core samples were obtained from the dirt overburden of a LASL low-level TRU waste burial trench. A split-spoon sampler $(7.5-\mathrm{cm}$ diam) was hammered to a depth of $120 \mathrm{~cm}$ in two successive 60 -

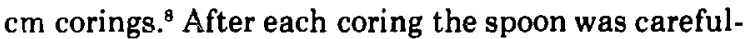
ly opened and each $10-\mathrm{cm}$ length was packaged in zip-lock-type polyethylene bags, labeled, quickfrozen in dry ice-ethanol, and stored in a dry-ice chest in the field; then they were stored at $-30^{\circ} \mathrm{C}$ in the laboratory for subsequent testinc. Table III shows that the number of culturable microorganisms decreases with soil-sample depth. Although the numbers are larger for the MPN method, the same trend is obvious for the CFU technique. We casually observed that the relative proportion of actinomycetes in the samples increased as the numbers of bacteria decreased with depth, ana at 100-110, cm few fungi could be detected. Nevertheless, more than 10000 microorganisms/g of soil were found in the 100 - to $110-\mathrm{cm}$ sample, which should correspond to a depth just above the top layer of buried low-level radioactive waste.

As shown in Table III, beta and gamma activities were greatest at a depth of $40-50 \mathrm{~cm}$ and lowest by an order of magnitude at $100-110 \mathrm{~cm}$. The reason for this elevated radioactivity at the intermediate depth

TABLE II

MPN MICROORGANISMS PER GRAM OF SOIL

\begin{tabular}{llll}
\multicolumn{1}{c}{ Medium } & \multicolumn{2}{c}{ Bacteria } & Fungi \\
\cline { 1 - 1 } & Aerobic & Anaerobic & \\
TSB & & & \\
$\quad 1: 10$ & $2.3 \times 10^{6}$ & & \\
$1: 100$ & $2.3 \times 10^{8}$ & & \\
$\begin{array}{l}\text { Thioglycollate } \\
\text { medium }\end{array}$ & & $3.3 \times 10^{6}$ & \\
$\begin{array}{l}\text { Sabouraud broth } \\
\text { with antibiotics }\end{array}$ & & & \\
$\quad$ & & $4.9 \times 10^{4}$
\end{tabular}




\section{TABLE III}

\section{ENUMERATION OF MICROFLORA IN LASL TRU SHALLOW BURIAL SITE (TA-54, AREA C) SOIL}

\begin{tabular}{|c|c|c|c|c|c|c|c|}
\hline \multirow{2}{*}{$\begin{array}{l}\text { Depth } \\
\text { (cm) }\end{array}$} & \multirow{2}{*}{$\begin{array}{c}\text { Radioactivity }^{\mathrm{a}} \\
\text { in soil }(\gamma, \beta)\end{array}$} & \multicolumn{3}{|c|}{ CFU/g Soil ${ }^{\mathbf{b}}$} & \multicolumn{3}{|c|}{ MPN/g Soilc } \\
\hline & & Aerobic & Anaerobic & Fungi & Aerobic & Anaerobic & Fungi \\
\hline $5-15$ & ND & $1.5 \pm 0.2 \times 10^{\mathrm{B}}$ & $2.8 \pm 0.4 \times 10^{3}$ & $3.5 \times 10^{3}$ & $\begin{array}{c}2.3 \times 10^{6} \\
(0.7-7.6)\end{array}$ & $\begin{array}{l}3.3 \times 10^{6} \\
(1.0-10.9)\end{array}$ & $\begin{array}{l}4.9 \times 10^{4} \\
(1.49-16.2)\end{array}$ \\
\hline $40-50$ & $4 \times 10^{4}, 6 \times 10^{4}$ & $1.3 \pm 0.1 \times 10^{5}$ & $1.4 \pm 0.8 \times 10^{2}$ & $5.8 \times 10^{2}$ & $\begin{array}{l}4.9 \times 10^{5} \\
(1.49-16.2)\end{array}$ & $\begin{array}{c}1.1 \times 10^{6} \\
(0.33-3.6)\end{array}$ & $\begin{array}{l}1.1 \times 10^{5} \\
(0.33-3.6)\end{array}$ \\
\hline $100-110$ & $2 \times 10^{3}, 7 \times 10^{3}$ & $4.5 \pm 1.7 \times 10^{4}$ & & $6.5 \times 10^{1}$ & $\begin{array}{l}3.3 \times 10^{4} \\
(1.0-10.9)\end{array}$ & $\begin{array}{c}3.3 \times 10^{4} \\
(1.0-10.9)\end{array}$ & $\begin{array}{c}2.3 \times 10^{2} \\
(0.70-7.6)\end{array}$ \\
\hline
\end{tabular}

"dpm/g soil.

'Mean and standard deviation of duplicate or triplicate plate counts.

"Numbers in parentheses are $95 \%$ confidence limits."

is not clear but may be due to decontamination of a piece of equipment in the field followed by backfilling with soil. Other possibilities could be cited, but until additional samples are analyzed, this phenomenon will not be discussed further. The gamma emitter was tentatively identified by the radiochemistry section of LASL Group CMB-1 as ${ }^{137} \mathrm{Cs}$; the beta emitters were not identified; and there was no detectable alpha activity.

Although the level of radioactivity was greatest in the 40 - to $50-\mathrm{cm}$ sample, the frequency of microorganisms was clearly not the lowest, so these levels of radioactivity apparently do not sterilize the soil.

E. Enumeration of Microflora in ${ }^{239} \mathrm{Pu}$ Contaminated Waste From a Steel Burial Drum

Some ${ }^{239} \mathrm{Pu}$-contaminated waste materials were retrieved from a steel drum in which combustibles had been deposited recently by LASL employees after work performed in gloveboxes in a plutonium work area. We opened the bags in a glovebox in the same work area, but we covered the working surface with clean nonradioactive aluminum foil. Each piece of waste material was handled with sterile forceps, pieces were cut from them with sterile scissors, and each piece was placed aseptically into a sterile Erlenmeyer flask containing $100 \mathrm{~m} \ell$ of Difco TSB and a sterile plastic-coated bar magnet. Each flask was stirred on a magnetic stirrer for $15 \mathrm{~min}$ at room temperature, after which a $5 \cdot \mathrm{m} \ell$ aliquot was diluted to a $1 \times 10^{5}$ dilution factor in TSB. After 14 days incubation at $28^{\circ} \mathrm{C}$, the tubes were scored and the MPN was calculated. ${ }^{6}$ Table IV shows the MPN for aerobic microorganisms and fungi. The anaerobic cultures were contaminated, so they were discarded.

\section{F. Enumeration of Microflora in Simulated TRU Waste Used for Gas Production and Chelate Degradation Studies at UNM}

The formula for simulated TRU waste, which contains celluloses, rubbers. and plastics, can be found in Ref. 7 . We cut the eight components by hand into small pieces and weighed them to allow 75 to $240 \mathrm{mg}$ of each component for a total of $1.0 \mathrm{~g}$. We added 9.0 $\mathrm{m} \ell$ of Difco TSB to the $1.0-\mathrm{g}$ portions and stirred the mixture on a magnetic stirrer for $15 \mathrm{~min}$. Aliquots were serially diluted and incubated for 14 days at $28^{\circ} \mathrm{C}$. An aliquot of the original mixture was streaked on TSA and on mycophil agar.

Table $V$ shows that only two gram-positive sporeforming bacilli were detected on the aerobically incubated petri dishes. These bacteria are the common soil and dust-borne bacteria found in most laboratories and will certainly be present in waste destined for the WIPP.

\section{G. Direct Enumeration of Microflora}

Soil samples were prepared as described for CFU and MPN estimates.' For microscopic examination, $0.01 \mathrm{~m} \boldsymbol{l}$ of $100 \mathrm{X}$ dilution of soil was spread over a 
TABLE IV

MICROFLORA IN ${ }^{239}$ Pu-CONTAMINATED WASTE

\begin{tabular}{|c|c|c|c|}
\hline \multirow[b]{2}{*}{ Waste Material } & \multicolumn{2}{|c|}{$\mathbf{M P N}^{a}$} & \multirow[b]{2}{*}{ Microflora on Solid Medium } \\
\hline & Aerobic & Fungi & \\
\hline Wood chips & $7.0 \times 10^{1}$ & ND & Gram + , spore-forming rods \\
\hline Kleenex box (end panel) & $1.1 \times 10^{2}$ & ND & Gram +, spore-forming rods \\
\hline PVC glove (2 fingers) & $9.5 \times 10^{3}$ & $4.6 \times 10^{1}$ & Gram,+ cocci \\
\hline Tissue (1) & $3.3 \times 10^{1}$ & ND & Gram + , rods \\
\hline Cotton gauze $\left(2 \mathrm{~cm}^{2}\right)$ & $3.3 \times 10^{1}$ & $\mathrm{ND}$ & No growth \\
\hline
\end{tabular}

TABLE V

MICROFLORAL CONTENT OF LASL SIMULATED WASTE USED FOR GAS EVOLUTION AND CHELATE DEGRADATION STUDIES AT UNM

\author{
MPN: $0.79 \times 10^{3 / g}$
}

Characteristics: 2 different (colony morphology), gram-positive, aerobic, spore-forming rods.

$1.0-\mathrm{cm}^{2}$ well on a microscope slide. The preparations were air-dried and slightly heat-fixed. We also prepared some slides with soil amended by the addition of an aliquot of a culture of gram-positive bacilli. Fixed slides were stained using the procedure described by Bubiuk and Paul [see Can. J. Microbiol. 16, 57-62 (1970)].

S!ides were stained for $3 \mathrm{~min}$ at room temperature, and washed in $0.5 \mathrm{M} \mathrm{NaHCO}, 5 \%$ $\mathrm{Na}_{4} \mathrm{P}_{5} \mathrm{O}$, buffer. The stained preparations were immediately mounted in glycerol and observed under the Zeiss Epi-fluorescence microscope.

Bacteria were easily seen on slide preparations containing amended soil and background staining was negligible, but no fluorescent microorganisms were seen in the unamended soil. This is probably because bacterial spores are impermeable to the stain, and because the small sample size limited the number of vegetative forms.

Since spores do not stain well, $0.01 \mathrm{ml}$ of a $100 \mathrm{X}$ dilution of soil was embedded in $1.5 \%$ Difco nutrient agar and incubated in a moist sterile chamber at $28^{\circ} \mathrm{C}$ for $2,18,22,42$, and 66 hours. The slides were fixed and stained as described above. As a control, $1.5 \%$ Difco nutrient agar was incubated without soil. We could not determine whether spores had germinated and formed microcolonies of vegetative forms because even the control slide fluoresced brightly. We concluded that the protein in nutrient agar stained with the FITC and could not be destained by the bicarbonate-pyrophosphate wash.

We conclude that although direct microbial enumeration by fluorescent microscopy works well for water samples, the procedure is not readily applicable to soil samples. 


\section{RADIOBIOLOGY OF LASL TRU WASTE (LASL)}

\section{A. Background}

Radiation-resistant microorganisms have been induced by ionizing radiations in the laboratory ${ }^{10}$ and in field conditions in which medical products were sterilized by radiation. " Selective enrichment of microbial populations for specific advantageous characteristics normally involves long-term radiation exposures at low dose rates that are minimally lethal to the microorganism.

The soil microflora from the shallow burial site soil samples, which have low levels of beta and gamma emitters, provided a long-term low-dose-rate experiment. To determine whether an elevated frequency of radiation-resistant bacteria live in soil samples with detectable radioactivity, we suspended $10 \mathrm{~g}$ of soil from depths of $5-15 \mathrm{~cm}, 40-50 \mathrm{~cm}$, and $100-110 \mathrm{~cm}$ in $95 \mathrm{~m} \ell$ of TSB and stirred for $15 \mathrm{~min}$ on magnetic stirrers. Aliquots were serially diluted, plated on the surface of TSA, and incubated for 7 days at $28^{\circ} \mathrm{C}$. Isolated colonies were stabbed in the center with sterile sticks and inoculated into TSB. Each turbid culture was looped onto five nutrient agar plates, and after $20 \mathrm{~min}$ of drying, the plates were irradiated with $250-\mathrm{kVp} x$ rays at a dose rate of 900 rads per min for total doses of $0,13.5,27,40.5$, and 54 krads. Bacillus subtilis (ATCC \#6051) was included on each plate as a radiation sensitivity reference standard. A survival key was formulated to permit at least a quasi-quantitative evaluation of survival of bacteria in the looped areas of each irradiated plate relative to the control unirradiated plates. An isolate was considered resistant if its survival did not decrease more than one step on the survival key. ${ }^{8}$ Similar evaluations were performed on the 5 - to $15-\mathrm{cm}$ sample, which lacked detectable radioactivity.

\section{B. Gamma-Radiation-Dose Response of Fadioresistant Isolates}

Ten isolates from the $40-$ to $50-\mathrm{cm}$ soil sample containing 20 to $30 \mathrm{nCi}$ of radioactivity, which survived 54 krads of $x$-irradiation, ${ }^{8}$ were inoculated into broth with the ingredients of Difco Actinomycete Isolation Agar minus the agar, and incubated overnight with shaking at $28^{\circ} \mathrm{C}$. The next morning, the cultures were in the logarithmic phase of growth as deter- mined by turbidometric readings in a Coleman $\mathrm{Jr}$. Colorimeter at a 600-nm wavelength. Each culture was diluted and pour-plated into Difco Actinomycete Isolation Agar. Bacillus subtilis (ATCC \#6051) was grown and plated for use as a control exhibiting "normal" radiation sensitivity, and Micrococcus radiodurans (ATCC $\# 13939$ ) was used as a strongly radioresistant control. All inoculated petri dishes were stored for up to 2.5 hours at $4^{\circ} \mathrm{C}$ and removed as needed for exposure to gamma radiation.

In previous radiobiological experiments, we used $250-\mathrm{kVP} \times$ rays at a dose rate of $900 \mathrm{rads} / \mathrm{min}$. The higher doses used in the experiments described here, however, demanded that we use another source of ionizing radiation. ${ }^{9}$ We irradiated 10 isolates and the two controls simultaneously in the sample chamber of a Gammacell 220 irradiation unit emitting highintensity gamma radiation from a ${ }^{60} \mathrm{Co}$ source at a calculated dose rate of $3058 \mathrm{rads} / \mathrm{min}$. Then the dishes were incubated at $28^{\circ} \mathrm{C}$ for $6-7$ days.

Table Vi shows that the radioresistance of these soil isolates was intermediate to that of the two controls. It would be desirable to determine the relative radioresistances of isolates from soil containing considerably less and considerably more radioactivity than the sample we examined.

\section{POTENTIAL ALKYLATION OF TRU ELE- MENTS (LASL)}

\section{A. Background}

Microorganisms are responsible for the alkylation of many elements, including the metals mercury, tin, palladium, platinum, gold, and thallium, and the metalloids arsenic, selenium, tellurium, and sulfur. ${ }^{12}$ When methylated, these elements become volatile and they become less polar, which increases their solubility in the lipids of biological tissues. Methylation occurs under both aerobic and anaerobic conditions..$^{12.13}$ The best studied alkylation reaction for metals is the methylation of mercury, which, like other metals, is methylated by the chemical transfer of methyl groups from methylcobalamine ${ }^{14}\left[\left(\mathrm{CH}_{3} \mathrm{~B} 12\right)\right.$, an analog of vitamin $\mathrm{B} 12$ and an intermediate product of bacterial metabolism]. This methyl donor was used to methylate mercury and in attempts to methylate the lanthanide element europium, and the actinide elements thorium and plutonium. 


\section{TABLE VI}

\section{GAMMA-RADIATION-DOSE RESPONSE OF RADIORESISTANT SOIL ISOLATES}

\begin{tabular}{|c|c|c|}
\hline \multirow{2}{*}{$\begin{array}{c}\text { Radiation } \\
\text { Dose } \\
\text { (krads) }^{\mathrm{H}}\end{array}$} & \multicolumn{2}{|c|}{ Controls ${ }^{\mathrm{b}}$} \\
\hline & B. subtilis & M. radiodurans \\
\hline 0 & 187 & 556 \\
\hline 25 & 5 & 493 \\
\hline 50 & 0 & 503 \\
\hline 75 & 0 & 381 \\
\hline 100 & 0 & 303 \\
\hline
\end{tabular}

\begin{tabular}{cccccccccc}
\multicolumn{10}{c}{ Radioresistant Isolates $^{\mathbf{c}}$} \\
\hline$\underline{\mathbf{5 9}}$ & $\underline{\mathbf{6 3}}$ & $\underline{\mathbf{5 7}}$ & $\underline{\mathbf{6 0}}$ & $\underline{\mathbf{3 4}}$ & $\underline{\mathbf{5 4}}$ & $\underline{\mathbf{4 8}}$ & $\underline{\mathbf{5 6}}$ & $\underline{\mathbf{1}}$ & $\underline{\mathbf{6}}$ \\
$\mathbf{4 1 2}$ & 211 & 96 & 128 & $\mathbf{5 7}$ & 34 & 109 & 0 & 78 & 308 \\
416 & 237 & 135 & 167 & 58 & 20 & 0 & 91 & 78 & 121 \\
235 & 13 & 66 & 64 & 4 & 5 & 7 & 38 & 6 & 0 \\
5 & 0 & 6 & 2 & 0 & 0 & 1 & 2 & 1 & 0 \\
0 & 0 & 0 & 0 & 0 & 0 & 0 & 0 & 0 & 0
\end{tabular}

"(

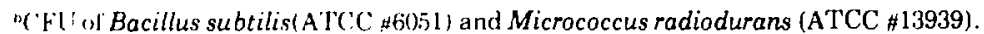

' $\mathrm{Fl}$ : on bacteria isolated from a $40.0050 \mathrm{~cm}$-deep core sam ple taken from a LASL TRU shallow burial site and containing 20 to 40 $n(i$ of beta and gamma activity. Heading numbers represent number of isolate.

As reported in Ref. 7, we could not detect a methylated form of europium using a variety of reaction conditions and detection methods. However, the question remained as to whether the heavy elements of the TRU series could be alkylated by the methyl donor produced by microorganisms.

We reported that $\mathrm{Th}\left(\mathrm{NO}_{3}\right)_{4} \cdot 4 \mathrm{H}_{2} \mathrm{O}$ appeared to be methylated, as indicated by the spectral shifts accompanying the demethylation of $\mathrm{CH}_{3} \mathrm{~B} 12 .^{7}$ We used $\mathrm{ThCl}_{4}$ instead of the nitrate salt and found a similar suggestion for methylation based on spectral shifts in the absorbance of $\mathrm{CH}_{3} \mathrm{~B} 12$. However, mass spectrometry determined that no methylated metal was formed, even though some demethylation and degradation of $\mathrm{CH}_{3} \mathrm{~B} 12$ occurred.

Direct chemical synthesis of methylthorium or methylplutonium has also been elusive because of the extreme affinity of these actinides for water molecules. These elements in the +4 valence state undergo extensive hydrolysis between $\mathrm{pH} 2.8$ and 7.5 because of their high ionic charge and relatively small radius of $0.90 \mathrm{~nm}$.

Our attempts to methylate these heavy metals were thwarted to some extent by the lack of their solubility above $\mathrm{pH} 3$. Below this $\mathrm{pH}$ the actinides are soluble, but the methyl donor $\mathrm{CH}_{3} \mathrm{~B} 12$ readily degrades. When we attempted to carry out the reactions at a higher $\mathrm{pH}$ (6-7) using Tris or phosphate buffers to stabilize $\mathrm{CH}_{3} \mathrm{~B} 12$, the inorganic thorium precipitated. Experiments were then designed to incorporate the organic buffer hexamethylenetetramine $\left[\left(\mathrm{CH}_{2}\right)_{6} \mathrm{~N}_{4}\right]$ with a $\mathrm{pH}$ of 5.0. A $0.2 \mathrm{M}$ solutiun of $\left(\mathrm{CH}_{2}\right)_{8} \mathrm{~N}_{4}$ buffered the methylation reaction at $\mathrm{pH} 6.4$ without apparent precipitation of thorium or breakdown of $\mathrm{CH}_{3} \mathrm{~B} 12$.

The pathways for the biologically mediated methylation of thorium or plutonium are not known. Methylation of actinide elements is difficult and probably requires specific physical, chemical, and biological conditions. An obvious extension of these experiments would be to try to methylate these elements using microbial cultures, and perhaps laboratory sod beds. It would also be interesting to set up some transalkylation reactions to determine whether the methyl group can be transferred from other metals to the actinides in a reaction similar to that described for the methylation of tellurium in the presence of excess selenium..$^{15}$

\section{B. Attempted Methylation of Plutonium}

A soluble form of plutonium is needed as a reactant in aqueous methyl transfer reactions. To satisfy this need quickly, we dissolved metallic ${ }^{238} \mathrm{Pu}$ (weapon grade) in $4 M \mathrm{HCl}$. We made two unsuccessful attempts to convert the resulting mixture of plutonium ions (predominantly III and IV) to the IV oxidation state. Although $\mathrm{Pu}(\mathrm{III})$ is reactive, the IV 
state is more reactive in general, and III-complexes are less stable. ${ }^{16}$

In the first experiment, we diluted the stock solution of plutonium in deionized water to a final acid concentration of $0.1 \mathrm{M} \mathrm{HCl}$. Then, to reduce the plutonium to the III oxidation state, we added $1 M$ $\mathrm{NH}_{2} \mathrm{OH} \cdot \mathrm{HCl}$ until the solution turned green. ${ }^{18} \mathrm{We}$ added $\mathrm{NaNO}_{2}$ to oxidize the III ions to the IV oxidation state and the solution became almost colorless. The solution was diluted in $0.1 \mathrm{M} \mathrm{HCl}$ and the absorption spectrum between 400 and $625 \mathrm{~nm}$ was determined on a Carey recording spectrophotometer. This scan showed that the plutonium had not been converted to the IV state, but displayed the spectrum of $\mathrm{Pu}$ (III).$^{16}$

All conditions were the same in the second experiment, except that the reduction and oxidation steps were performed on the concentrated stock of plutonium ( $85.3 \mathrm{mM}$ in $4 \mathrm{M} \mathrm{HCl}$ ) before diluting the acid to $0.1 M$. Again, a spectral scan showed no indication of the IV state, but indicated that the plutonium had polymerized. ${ }^{17}$

The $0.1 \mathrm{M} \mathrm{HCl}$ was adopted as plausible since higher concentrations of mineral acids are not com. patible with most living microorganisms that can produce methylcobalamine. We also felt that higher acid concentrations would probably affect the organic molecule of the methyl donor, methylcobalamine.

In any event, we stopped the experiments when we learned that it was highly unlikely that we would detect any plutonium in a methylated form due to the short half-life of alkylated actinides. ${ }^{18-20}$

\section{SOLUBILIZATION OF PLUTONIUM BY A CHELATE OF MICROBIAL ORIGIN (LASL- UNM)}

\section{A. Background}

Chelates of microbial origin may be found where het erot rophic microorganisms exist that require iron or other metals. ${ }^{21}$ Hydroxamates and interchelins are strong metal complexing molecules produced when bacteria grow in an iron-deficient environment. ${ }^{22}$ These chelates enhance the dissolution of the metals with which they complex, and therefore, have the potential of increasing their mobilities. The mobilization of TRU elements in radioactive-waste disposal sites by both naturally occurring and man-made chelates such as those used in decontamination procedures was considered to be a real possibility. We initiated this area of experimentation using the commercially available polyhydroxamate Desferol. Unfortunately, the lack of continued funding will not permit the LASL Life Sciences Division to continue these experiments and to include experiments designed to demonstrate whether microbial cultures would mobilize plutonium via chelation. However, these experiments may be continued by UNM in collaboration with LASL Group CMB-1.

\section{B. Dissolution of Plutonium by a Polyhydrox- amate Chelate}

The experimental design was to place insoluble $\mathrm{PuO}_{2}$ and the chelating agent together in water. The dioxide of weapon-grade ${ }^{239} \mathrm{Pu}$ and Desferol, a modified ferrioxamine, ${ }^{21}$ were used in the following experiments. The $\mathrm{pH}$ ranged from 5.5 to 6.0 due to variations in $\mathrm{pH}$ of the deionized water.

In the first experiment, $\mathrm{PuO}_{2}$, Desferol, and blue dextran in $10 \mathrm{~m} \ell$ of water were placed in a collodian dialysis membrane and immersed in a cylinder containing $200 \mathrm{~m} \ell$ of water. The high-molecular-weight dye was added to help detect breaks in the membrane. Concentrations of each component and other specifics were reported in Ref. 9. Even though the membrane ruptured after 10 days, aliquots were taken from the $200-\mathrm{m} \ell$ mixture, centrifuged to remove $\mathrm{PuO}_{2}$ polymers. and counted to determine solubilized radioactivity. A consistent increase in counts over 20 days suggested chelate-mediated solubilization of plutonium (Table VII). Chromatographic separation on Sephadex G10 resulted in two peaks of radioactivity, as shown in Fig. 1. In a similar chromatographic run in which $\mathrm{FeCl}_{3}$ was added, brown Desferol-Fe (III) appeared in the first peak. These results suggested that the plutonium in this peak was complexed with Desferol.

In the next experiment, ${ }^{238} \mathrm{PuO}_{2}$ and Desferol were placed in $140 \mathrm{~m} \ell$ of water and a collodian membrane containing $5 \mathrm{ml}$ of water was immersed in it. Aliquots were removed from inside and outside the membrane daily for 35 days, centrifuged, and the superiatants counted. The data reported in Ref. 10 showed more than a threefold increase in solubilized counts over a 20-day period, whereas the control with only $\mathrm{PuO}_{2}$ showed no increase. 
TABLE VII

DISSOLUTION OF ${ }^{23} \mathbf{P u O}_{2}$ IN DESFEROL

\begin{tabular}{|c|c|c|c|c|}
\hline \multirow{3}{*}{$\begin{array}{c}\text { Sample } \\
\text { Time (Days) }\end{array}$} & \multicolumn{4}{|c|}{ Net ${ }^{\mathrm{a}}$ CPM per $100 \mu \ell$} \\
\hline & \multicolumn{2}{|c|}{ Inside Membrane } & \multicolumn{2}{|c|}{ Outside Membrane } \\
\hline & Contro] & $\underline{\operatorname{Expt}} \mathbf{t}^{\mathrm{b}}$ & Control & Expt $J^{c}$ \\
\hline 0 & 2.5 & 31 & & \\
\hline 5 & 5.0 & 41 & 219 & 1137 \\
\hline 11 & 2.4 & 35 & 124 & 2234 \\
\hline 20) & 0 & 36 & 187 & 3473 \\
\hline
\end{tabular}

Chromatographic separation of aliquots was ab. tained again on Sephadex fi10 as described in Ref. 9. Two peaks of radioactivity resulted, as in the previous experiment; a Ferric ion-Desierol complex eluted with the first pesk, again suggesting a piutonium-Desferol complex.

In an attempt to determine the nature of the material in the first peak (Fig. 1), which might contain chelated $\mathrm{Pu}(\mathrm{IV})$ ions, a sample was taken from the first exierimental cylinder (described above), centrifuged, chromatographed on Sephadex G10, and the fractions under the first peak were pooled. Based on total count the peak contained $3 \times 10^{4}$ $\mu$ moles of plutonium. An absorption spectrum of this solution was compared with spectra of solutions of $\mathrm{Pu}(\mathrm{IV})$ ions with and without Desferol and with Desferol only (Fig. 2). The pooled experimental fractions had an absorption maximum at $\mathrm{A}_{304} \mathrm{~nm}$, $\mathrm{Pu}(\mathrm{IV})$ ions plus Desferol at a broad peak from 325 to $400 \mathrm{~nm}$, the plutonium ions exhibited no maximum, and Desferol had virtually no absorption. Similar absorption profiles have been observed for hydroxamate-Fe(III) complexes. ${ }^{21}$

To further characterize the plutonium in both peaks eluted from the G10 column, the fractions under each peak were pooled and an aliquot was extracted with a mixture of phenol:chloroform $(1: 1)$. Mixtures of $\mathrm{Pu}(\mathrm{IV})$ and Desferol prepared at specific concentrations and in various ratios were also extracted with this solvent. Chelated metal ions are soluble in phenol:chloroform while the unchelated metals are soluble in an aqueous phase. ${ }^{23}$

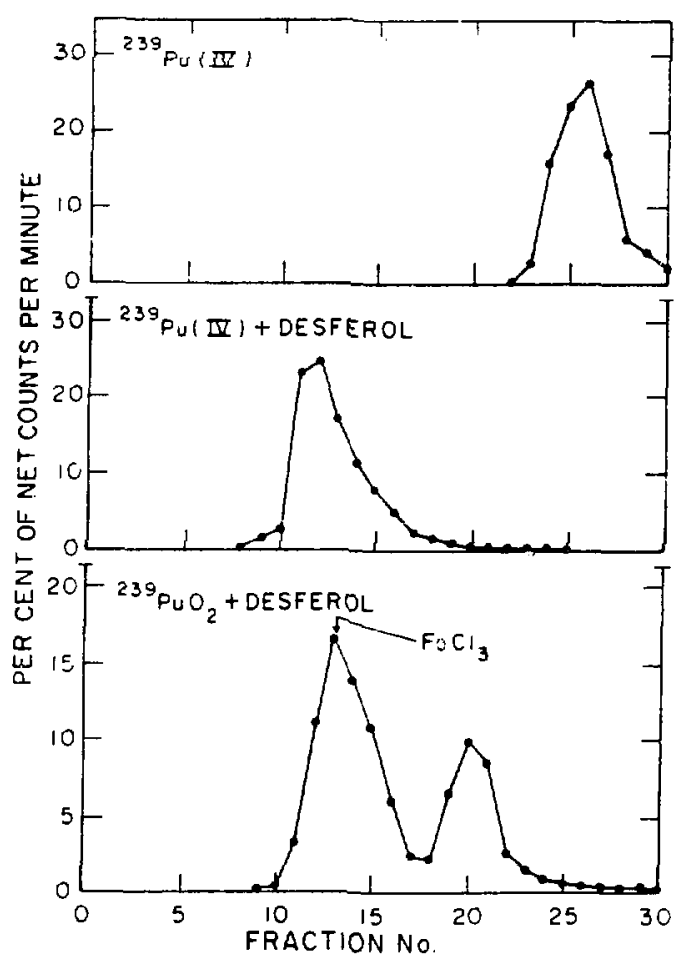

Fig. 1 .

Chromatographic separation of plutonium ions and plutonium-Desferal complex. The material was eluted from a Sephadex G-10 column $(1 \times 20 \mathrm{~cm})$ with $0.1 \mathrm{M} \mathrm{HCl}$ in $10 \%$ ethanol. The Desferol chelate of $\mathrm{Fe} \mathrm{Cl}_{3}$ eluted simultaneously with the more rapidly eluting radioactivity believed to be a plutoniumDesferol chelate. 


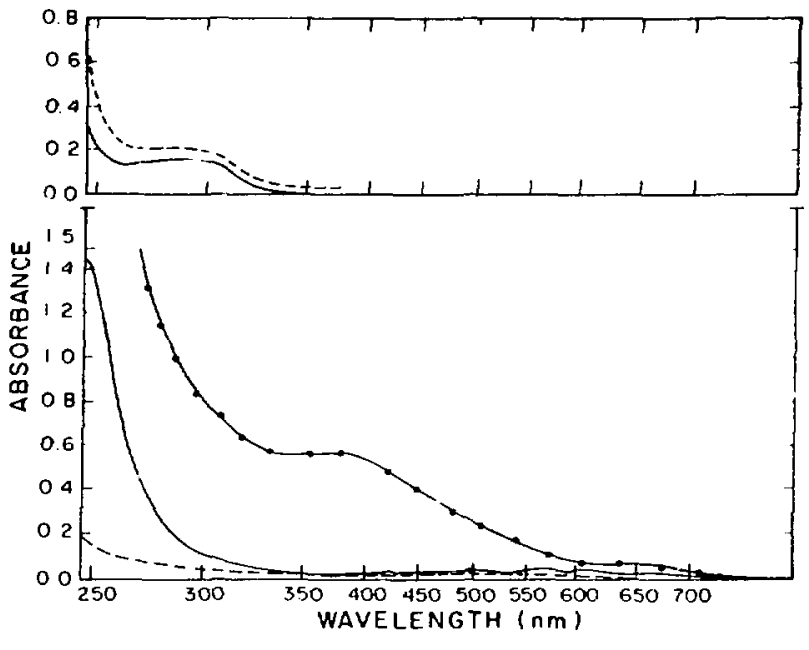

Fig. 2.

Upper panel, ultraviolet absorption spectra of rapidly eluting material from a Sephadex $G-10$ column. Lower panel, ultraviolet absorption spectra of ${ }^{238} \mathrm{Pu}(I V)$-Desferol complex $(\cdot-\cdot)$, ${ }^{239} \mathrm{Pu}(I V)$ ions (-) and Desferol (-- -).

Extraction of peak 1 resulted in $69 \%$ of the radioactivity partitioned in the organic phase. We extracted $26 \%$ of the radioactivity from a mixture of $2.2 \times 10^{-2} \mathrm{M} \mathrm{Pu}(\mathrm{IV})$ and $4.6 \times 10^{-2} \mathrm{M}$ Desferol, pH 1.0. On the other hand, radioactivity from a control solution of $\mathrm{Pu}(\mathrm{IV})$ ions partitioned into the aqueous phase. All of the detectable radioactivity in the second Sephadex G10 peak was also exiracted into the aqueous rather than the organic phase. These results support further the possibility that under appropriate conditions, plutonium can se chelated by at least one microbially produced chelate, Desferol.

\section{CARBON DIOXIDE GAS GENERATION STUDIES (UNM)}

\section{A. Background}

The generation of $\mathrm{CO}_{2}^{\cdot}, \mathrm{H}_{2} \mathrm{~S}, \mathrm{CH}_{4}, \mathrm{O}_{2}, \mathrm{NO}, \mathrm{N}_{2} \mathrm{O}$, and $\mathrm{SO}_{2}$ by simulated organic TRU waste (LASL composite waste, $34 \%$ cellulose, $24 \%$ polyethylene, $12 \%$ polyvinyl chloride, $7.5 \%$ each of neoprene, latex, hypalon, and butyl rubber), CM cellulose, bovine serum albumen, and asphalt were studied in FY 78. These preliminary studies showed that $\mathrm{CO}_{2}$ was the predominant gas formed aerobically unless proteinaceous organic matter was present, in which case, small quantities of $\mathrm{H}_{2} \mathrm{~S}$ were also produced. Also, the simulations did not adequately model anaerobic conditions since no methane was produced. As a result, studies of gas generation in FY 79 focused on $\mathrm{CO}_{2}$ evolution..$^{\theta \cdot \theta}$ Simulations of anaerobic gas generation are planned for FY 80 . The following treatments were used: aerobic, $\mathrm{N}_{2}$-purged (anaerobic), $25^{\circ} \mathrm{C}, 40^{\circ} \mathrm{C}, 70^{\circ} \mathrm{C}, 1 \% \mathrm{H}_{2} \mathrm{O}, 91 \% \mathrm{H}_{2} \mathrm{O}$, $91 \%$ brine, and nutrient solution. ${ }^{24}$ The present study was to determine the effects of brine, temperature, nutrient addition, and waste composition (alone and in various combinations) on gas generation. Sawdust, asphalt, and LASL composite waste were used as substrates. There were no replicates due to the large number of treatments. However, replicates are planned for FY 80 to provide confidence intervals on gas production rates for key treatments.

\section{B. Rates of Carbon Dioxide Generation}

The mean rate of carbon dioxide generation for the 72 simulations (with sterile controls) was 5.97 $\mu \mathrm{g} / \mathrm{day} / \mathrm{g}$ with a standard deviation of 3.33 . The results from each simulation are given in Tables VIII-X for simulated organic matrix TRU waste (LASL composite waste), asphalt, and sawdust, respectively. As seen in Table XI, despite the effects of oxygen, water, brine, and nutrient addition, temperature shows a positive correlation with gas generation rates for all three substrates. Varying the oxygen tension, concentration of water, nutrient level, and the addition of brine had no significant effect on rates of degradation at the levels tested (across treatments).

Gas chromatography consistently gave lower results than the alkaline absorption method for measuring rates of $\mathrm{CO}_{2}$ evolution because of the loss of $\mathrm{CO}_{2}$ during incubations over periods of months $\left(\mathrm{CO}_{2}\right.$ diffused from the test ampoules). Thus the alkaline absorption technique is more accurate because it traps $\mathrm{CO}_{2}$ as it forms, preventing the pressurization of the test ampoules and consequent loss of product.

Both $1 \% \mathrm{H}_{2} \mathrm{O}$ and saturated salt brine provided enough water for biological degradation to occur. The rates of $\mathrm{CO}_{2}$ generation under extreme conditions (high temperature, high salt, and anaerobiosis) had a much higher standard deviation than the rates observed under moderate conditions. This suggests 
TABLE VIII

MICROBIAL PRODUCTION OF $\mathrm{CO}_{2}$ FROM SIMULATED ORGANIC MATRIX TRU WASTE (LASL COMPOSITE WASTE)"

\begin{tabular}{|c|c|c|}
\hline $\begin{array}{c}\text { Rate } \\
(\mu \mathrm{g} / \text { day } / \mathrm{g})^{\mathrm{b}} \\
\end{array}$ & $\begin{array}{c}\text { Kate } \\
(\mu \mathrm{g} / \mathrm{day} / \mathrm{g})^{\mathrm{c}} \\
\end{array}$ & Treatmen \\
\hline \multicolumn{3}{|c|}{ Aerobic } \\
\hline & & $25^{\circ} \mathrm{C}$ \\
\hline $\begin{array}{l}2.1 \\
0.3 \\
\cdots \\
\cdots\end{array}$ & $\begin{array}{c}3.8 \\
\text { none detected } \\
\text { none detected } \\
7.2\end{array}$ & $\begin{array}{l}91 \% \mathrm{H}_{2} \mathrm{O} \\
1 \% \mathrm{H}_{2} \mathrm{O} \\
\text { brine } \\
\text { nutrient } \\
\quad \mathbf{4 0}^{\circ} \mathrm{C} \\
\end{array}$ \\
\hline $\begin{array}{l}\cdots \\
\cdots \\
\cdots\end{array}$ & $\begin{array}{r}4.3 \\
3.1 \\
12.3 \\
3.6\end{array}$ & $\begin{array}{l}91 \% \mathrm{H}_{2} \mathrm{O} \\
1 \% \mathrm{H}_{2} \mathrm{O} \\
\text { brine } \\
\text { nutrient } \\
70^{\circ} \mathrm{C} \\
\end{array}$ \\
\hline $\begin{array}{c}0.3 \\
0.026 \\
\ldots \\
\ldots\end{array}$ & $\begin{array}{r}7.2 \\
9.8 \\
12.7 \\
10.7\end{array}$ & $\begin{array}{l}91 \% \mathrm{H}_{2} \mathrm{O} \\
1 \% \mathrm{H}_{2} \mathrm{O} \\
\text { brine } \\
\text { nutrient }\end{array}$ \\
\hline \multicolumn{3}{|c|}{ Angerobic } \\
\hline & & $25^{\circ} \mathrm{C}$ \\
\hline $\begin{array}{c}2.8 \\
0.053 \\
\ldots \\
\ldots\end{array}$ & $\begin{array}{r}9.9 \\
5.5 \\
7.4 \\
11.6\end{array}$ & $\begin{array}{l}91 \% \mathrm{H}_{2} \mathrm{O} \\
1 \% \mathrm{H}_{2} \mathrm{O} \\
\text { brine } \\
\text { nutrient } \\
\\
\mathbf{4 0}^{\circ} \mathrm{C} \\
\end{array}$ \\
\hline $\begin{array}{l}\cdots \\
\cdots \\
\cdots \\
\cdots\end{array}$ & $\begin{array}{r}1.5 \\
6.2 \\
18.4 \\
3.3\end{array}$ & $\begin{array}{l}91 \% \mathrm{H}_{2} \mathrm{O} \\
1 \% \mathrm{H}_{2} \mathrm{O} \\
\text { brine } \\
\text { nutrient } \\
70^{\circ} \mathrm{C} \\
\end{array}$ \\
\hline $\begin{array}{c}\text { none detected } \\
\text { none detected } \\
\ldots \\
\ldots\end{array}$ & $\begin{array}{c}8.0 \\
11.9 \\
\text { none detected } \\
17.0\end{array}$ & $\begin{array}{l}91 \% \mathrm{H}_{2} \mathrm{O} \\
1 \% \mathrm{H}_{8} \mathrm{O} \\
\text { brine } \\
\text { nutrient }\end{array}$ \\
\hline
\end{tabular}

"Net rates after subtraction of sterile controls. -Determined by gas chromatography ( $\mu \mathrm{g} \mathrm{CO}_{2}$ generated/g waste/dey).

cDetermined by titration of $\mathrm{Ba}(\mathrm{OH})$, trap for carbon dioxide.
TABLE IX

\section{MICROBIAL PRODUCTION OF $\mathrm{CO}_{2}$ FROM ASPHALT ${ }^{a}$}

\begin{tabular}{|c|c|c|}
\hline $\begin{array}{c}\text { Pate } \\
(\mu \mathrm{g} / \text { day } / \mathrm{g})^{\mathrm{b}}\end{array}$ & $\begin{array}{c}\text { Rate } \\
(\mu \mathrm{g} / \mathrm{day} / \mathrm{E})^{\mathrm{c}}\end{array}$ & Treaiment \\
\hline \multicolumn{3}{|c|}{ Aerobic } \\
\hline & & $25^{\circ} \mathrm{C}$ \\
\hline $\begin{array}{c}1.0 \\
\text { none detected } \\
\ldots \\
\ldots\end{array}$ & $\begin{array}{l}3.0 \\
\cdots-. \\
2.3 \\
3.3\end{array}$ & $\begin{array}{l}91 \% \mathrm{H}_{2} \mathrm{O} \\
1 \% \mathrm{H}_{2} \mathrm{O} \\
\text { brine } \\
\text { nutrient } \\
\quad 40^{\circ} \mathrm{C}\end{array}$ \\
\hline $\begin{array}{l}\cdots \\
\cdots \\
\cdots \\
\cdots\end{array}$ & $\begin{array}{l}\ldots . \\
0.8 \\
\ldots \\
0.9\end{array}$ & $\begin{array}{l}91 \% \mathrm{H}_{2} \mathrm{O} \\
1 \% \mathrm{H}_{2} \mathrm{O} \\
\text { brine } \\
\text { nutrient } \\
\quad 70^{\circ} \mathrm{C}\end{array}$ \\
\hline $\begin{array}{c}\text { none detected } \\
\text { none detected } \\
\ldots \\
\ldots\end{array}$ & $\begin{array}{c}\ldots . \\
7.4 \\
8.3 \\
\text { Anaerobic }\end{array}$ & $\begin{array}{l}91 \% \mathrm{H}_{2} \mathrm{O} \\
1 \% \mathrm{H}_{2} \mathrm{O} \\
\text { brine } \\
\text { nutrient }\end{array}$ \\
\hline & & $25^{\circ} \mathrm{C}$ \\
\hline $\begin{array}{c}0.26 \\
\text { none detected } \\
\ldots \\
--\end{array}$ & $\begin{array}{l}0.5 \\
4.3 \\
-.- \\
3.9\end{array}$ & $\begin{array}{l}91 \% \mathrm{H}_{2} \mathrm{O} \\
1 \% \mathrm{H}_{2} \mathrm{O} \\
\text { brine } \\
\text { nut sient } \\
\quad 40^{\circ} \mathrm{C}\end{array}$ \\
\hline $\begin{array}{l}1.7 \\
0.8 \\
0.8 \\
0.3\end{array}$ & $\begin{array}{l}\cdots \\
\cdots \\
\cdots \\
\cdots\end{array}$ & $\begin{array}{l}91 \% \mathrm{H}_{2} \mathrm{O} \\
1 \% \mathrm{H}_{2} \mathrm{O} \\
\text { brine } \\
\text { nutrient } \\
\quad 70^{\circ} \mathrm{C}\end{array}$ \\
\hline $\begin{array}{c}\text { none detected } \\
\text { none detected } \\
-.- \\
\ldots\end{array}$ & $\begin{array}{l}1.7 \\
6.0 \\
1.4 \\
\cdots\end{array}$ & $\begin{array}{l}91 \% \mathrm{H}_{2} \mathrm{O} \\
1 \% \mathrm{H}_{2} \mathrm{O} \\
\text { brine } \\
\text { nutrient }\end{array}$ \\
\hline
\end{tabular}

-Net rates after subtraction of sterile controls. 'Determined by gas chromatography ( $\mu \mathrm{g} \mathrm{CO}$, generated/g waste/day).

'Determined by tritration of $\mathrm{Ba}(\mathrm{OH})$, trap for carbon dioxide. 
TABLE X

\section{MICROBIAL PRODUCTION OF $\mathrm{CO}_{2}$ FROM SAWDUST}

Aerobic

\begin{tabular}{|c|c|}
\hline $\begin{array}{c}\text { Rate } \\
(\mu \mathrm{g} / \text { day } / \mathrm{g})^{\prime \prime}\end{array}$ & Treatment \\
\hline & $25^{\circ} \mathrm{C}$ \\
\hline $\begin{array}{r}11.2 \\
2.4 \\
0.0 \\
13.0\end{array}$ & $\begin{array}{l}91 \% \mathrm{H}_{2} \mathrm{O} \\
1 \% \mathrm{H}_{2} \mathrm{O} \\
\text { brine } \\
\text { nutrient }\end{array}$ \\
\hline & $40^{\circ} \mathrm{C}$ \\
\hline $\begin{array}{l}8.1 \\
5.1 \\
9.1 \\
2.2\end{array}$ & $\begin{array}{l}91 \% \mathrm{H}_{2} \mathrm{O} \\
1 \% \mathrm{H}_{2} \mathrm{O} \\
\text { hrine } \\
\text { nutrient }\end{array}$ \\
\hline 2.2 & $70^{\circ} \mathrm{C}$ \\
\hline $\begin{array}{r}2.8 \\
5.0 \\
14.6 \\
14.1\end{array}$ & $\begin{array}{l}91 \% \mathrm{H}_{2} \mathrm{O} \\
1 \% \mathrm{H}_{2} \mathrm{O} \\
\text { brine } \\
\text { nutrient }\end{array}$ \\
\hline
\end{tabular}

Anaerobic

$25^{\circ} \mathrm{C}$

20.6

8.9

9.3

9.6

3.7

13.5

18.7

5.4

$91 \% \mathrm{H}_{2} \mathrm{O}$

$1 \% \mathrm{H}_{2} \mathrm{O}$

brine

nutrient

$40^{\circ} \mathrm{C}$

$91 \% \mathrm{H}_{2} \mathrm{O}$

$1 \% \mathrm{H}_{2} \mathrm{O}$

brine

nutrient

$7^{\circ} \mathrm{C}$

18.1

13.6

5.4

9.9 that a lag period is required for microbial adaptation to occur. During this period, organisms (enriched) that can survive under adverse conditions may be selected. Long-term enrichments under these conditions would yield organisms capable of more rapid degradation rates. Thus, the in situ rates of gas generation in the WIPP facility, after an initiai adaptation period, will probably be higher than in short (1- to 2-yr) simulations. Due to the variability in the concentration of salt, humidity, substrates present, microflora present, temperature, and inorganic nutrient availability, it is rot possible to accurately forecast the rate of $\mathrm{CO}_{2}$ evolution unless these conditions are defined. However, the conditions most likely to produce biological gas generation are the addition of brine to wastes and the storage of wastes under humid conditions. The present results confirm this. As a result the simulated organic matrix TRU waste (LASL composite waste) will be incubated in brine and at $100 \%$ relative humidity with 10 replicates and 3 sterile controls (total of 23 simulations). The large number of replicates will allow an analysis of variation in the rates of gas generation. In addition, a duplicate set of flasks will be purged with nitrogen and amended with iron sulfide to lower the redox potential sufficiently to obtain rates of methanogenesis. ${ }^{26}$ Preliminary results show that this treatment provides strictly anaerobic conditions despite the presence of oxygen, which is continuously scavenged by the ferrous sulfide reductant.

The limit of detection for the $\mathrm{Ba}(\mathrm{OH})_{2}$ titration procedure was $0.01 \mathrm{mg} \mathrm{CO} / \mathrm{g}$ of waste. Simulations were sampled every 30-60 days. The total amount of waste in the simulations planned for FY 80 has been increased from 1 to $25 \mathrm{~g}$ to increase the sensitivity of the procedure to $0.40 \mu \mathrm{g} / \mathrm{g}$. In addition, $\mathrm{NaC} .4$ will replace $\mathrm{Ba}(\mathrm{OH})_{2}$ because the $\mathrm{BaCO}_{3}$ precipitate that formed as the $\mathrm{CO}_{2}$ was trapped reduced the efficiency of trapping. An equal volume of an equimolar solution of $\mathrm{BaCl}_{2}$ is added to the $\mathrm{NaOH}$ after incubation, before titration.

All the simulations involved only $1 \mathrm{~g}$ of waste material. When these results are scaled up to $\mathrm{kg}$ quantities, the time course and magnitude of degradation may vary from that found in the small simulations. In addition, highly biodegradable materials (insects, rodents, etc.) that may occur in situ could greatly increase the rate of gas generation from cellulosics and other more refractory organics.

aDetermined by titration of $\mathrm{Ba}(\mathrm{OH})$, trap for carbon dioxide. 


\section{TABLE XI}

\section{AVERAGE RATES OF $\mathrm{CO}_{2}$ GENERATION" (ACROSS TREATMENTS) IN $72 \mathrm{CO}_{2}$ SIMULATIONS (WITH STERILE BACKGROUND CONTROLS)}

\begin{tabular}{|c|c|c|c|}
\hline Conditions & LASL Composite & Sawdust & Asphalt \\
\hline $25^{\circ} \mathrm{C}$ & $5.1(3.9)^{\mathrm{b}}$ & $9.4(6.3)$ & $2.3(1.5)$ \\
\hline $40^{\circ} \mathrm{C}$ & $6.5(5.8)$ & $8.2(5.5)$ & $0.98(0.4$ \\
\hline $70^{\circ} \mathrm{C}$ & $8.6(5.5)$ & $10.4(5.5)$ & $4.9(3,2)$ \\
\hline aerohic & $4.8(4.6)$ & $7.3(5.1)$ & $3.4(2.9)$ \\
\hline anaerobic & $7.4(5.8)$ & $11.4(5.6)$ & $2.0(1.9)$ \\
\hline $91 \% \mathrm{H}_{2} \mathrm{O}$ & $4.45(3.5)$ & $10.8(7.4)$ & $1.0(1.0)$ \\
\hline $1 \% \mathrm{H}_{2} \mathrm{O}$ & $3.8(4.7)$ & $8.1(4.7)$ & $2.0(2.5)$ \\
\hline $91 \%$ brine & $2.9(3.0)$ & $11.4(5.2)$ & $2.9(3.0)$ \\
\hline nutrient & $8.9(5.3)$ & $9.0(4.5)$ & $3.4(3.2)$ \\
\hline
\end{tabular}

"Standard deviation given in parentheses.

'Rate of $\mathrm{CO}_{2}$ generation given as $\mu \mathrm{g} / \mathrm{day} / \mathrm{g}$.

The initial linear rates of $\mathrm{CO}_{2}$ evolution given here do not necessarily reflect long-term degradation rates. Rates should decline over a period of years due to the depletion of labile organics, leaving more refractory compounds to degrade at a slower rate. If there is pressurization due to gas evolution, the rate may decline further.

\section{CHELATE DEGRADATION STUDIES (UNM)}

\section{A. Background}

The chelate degradation studies and methodology described in Ref. 7 were preliminary studies of chelate degradation using europium as an analog of plutonium. Studies of plutonium chelates planned for FY 80 at LASL have been canceled.

\section{B. Results}

Results of europium chelate degradation, given in Tables XII-XIV, show that citrate, EDTA, and NTA, with europium chloride present in 10 -fold molar excess, were biodegraded under simulated WIPP conditions. The average half-life (across treatments) for NTA was 7.9 years (std dev, 4.0 years); for EDTA, 27.9 years (std dev, 21.5 years); and for citrate, 3.2 years (std dev, 2.0 years). The temneratures stuudied $\left(70\right.$ and $25^{\circ} \mathrm{C}$ ) were boundary conditions expected for the WIPP. ${ }^{28}$ However, intermediate temperatures near $40^{\circ} \mathrm{C}$, the optimum for most mesophilic microorganisms, would probably yield more rapid degradation rates. Rates of tartarate degradation are not given because the autoclave procedure for the sterilization of controls resulted in the decomposition of tartarate to $\mathrm{CO}_{2}$. As a result, the sterile controls showed more $\mathrm{CO}_{2}$ generation than the biological treatments.

Although each chelate degraded, the rates were low. This suggests that lanthanide coordination complexes are refractory, having half-lives of several years in WIPP simulations. The minimum sensitivity of the assay was $0.074 \%$ degradation. This represents a total of $2.3 \times 10^{-3} \mu \mathrm{Ci}(50 \mathrm{dpm}$ of the radioactive europium tracer) degraded to $\mathrm{CO}_{2}$, trapped, and detected by scintillation counting. A minimum of $3.1 \times 10^{-2} \mu \mathrm{Ci}(68000 \mathrm{dpm})$ of europium, thorium, and sodium chelates in soil are being run to determine whether the cause of low degradation rates is the lanthanides, actinides, or conditions in the WIPP simulations. All simulations involved $1 \mathrm{~g}$ of waste material. If these are scaled up to $\mathrm{kg}$ quantities, the time course and magnitude of degradation may vary fron that found in the simulations. In addition, the presence of highly 
biodegradable materials (insects, rodents, etc.), which may occur in waste packages sent to WIPP, could greatly increase chelate degradation due to ccmetabolism.

\section{IDENTIFICATION AND ENUMERA- TION OF MAJOR GROUPS OF MICRO- ORGANISMS IN WIPP SALT BEDS (UNM)}

No halophiles or other bacteria were found in surface sterilized crystals taken from the salt formations at the WIPP site. ${ }^{9}$

\section{CONCLUSIONS (LASL-UNM)}

The numbers of culturable bacteria found in radioactive LASL TRU burial site soil and flammable waste contaminated with ${ }^{230} \mathrm{Pu}$ show that populations of microorganisms coexist quire well with radionuclides, including weapon-grade plutonium. These are viable, metabolically active microbes whose potential effects on long-term storage of radioactive wastes must not be overlooked. These effects incluite possible mobilization by microbially produced cheiates that, as we have shown, can mediate dissolution of essentially insoluble plutonium dioxide, and by possible gas pressurization of radioactive waste storage vessels or enclosures as the result of microbially produced carbon dioxide. An analysis of the experimental results over the course of this project shows that microorganisms produce far more gas than that produced by physical or chemical processes. ${ }^{28}$

We investigated the relative radiation sensitivities of bacteria isolated from radioactive shallow burial site soil. As many as $68 \%$ of the bacteria from soil exhibiting gamma and beta radioactivity were more resistant than the common soil bacterium Bacillus subtilis to ionizing radiation, i.e., $\mathrm{x}$ and ganma radiation. Approximately $25 \%$ of the isolates from nonradioactive soil were.more resis'sant than $B$. sub. tilis. Although the radioresistant bacteria were less resistant than Micrococcus radiodurans, our results showed that microbes not only flourish in soil containing nanocurie levels of alpha and beta activity, but that this selective pressure results in elevat/2d frequencies of radiation-resistant bacteria.

These results indicate that the potential effects of microbial interactions with radioactive waste are not limited to laboratory situations but must be considered in designing long-term radwaste storage capabilities. Reduction or elimination of organic carbon sources in radionuclide-contaminated waste would reduce the numbers of heterotrophic microorganisms. The effects of chemosynthetic bacteria on the integrity of inorganic waste and waste containers has not been considered. ${ }^{27}$

\section{PROPOSED RESEARCH FOR FY 80}

Gas generation studies will continue through FY 80 at UNM. The surrent simulations will be continued until the rates of generation decrease to zero. New simulations will also be initiated to provide a confidence interval on gas generation rates and to determine $\mathrm{CH}_{4}$ production rates under strict anaerobic conditions (in addition to $\mathrm{CO}_{2}$ production). The simulated organic matrix TRU waste (LASL composite waste) will be incubated in brine at $100 \%$ relative humidity with 10 replicates and 3 sterile controls to allow an accurate statistical analysis of gas generation rates. A duplicate set of flasks will be purged with nitrogen and amended with iron sulfide to lower the redox potential enough to obtain rates of methanogenesis. Preliminary results show that this treatment provides strict anaerobic conditions despite the presence of oxygen, which is continuously scavenged by the ferrous sulfide reductant.

The limit of detection for the $\mathrm{Ba}(\mathrm{OH})_{2}$ titration procedure was $0.01 \mathrm{mg} \mathrm{CO} / \mathrm{g}$ of waste. Simulations were sampled c very 30-60 days. The total amount of waste in simulations planned for FY 80 has been increased from 1 to $25 \mathrm{~g}$ to increase the assay sensitivity to $0.4 \mu \mathrm{g} / \mathrm{g}$. In addition, $\mathrm{NaOH}$ will replace $\mathrm{Ba}(\mathrm{OH})_{2}$ in the traps since the $\mathrm{BaCO}$, precipitate that forms as the $\mathrm{CO}_{2}$ is trapped reduces the efficiency of $\mathrm{CO}_{2}$ detection.

Studies (conducted in collaboration with LASL's CMB Division) of the effect of plutonium on microbial gas generation and microbial viability have begun and will be described in another report. 
EUROPIUM-NTA CHELATE DEGRADATION (NET RATES AFTER SUBTRACTION OF STERILE CONTROLS)

Rate

$\langle \%$ degraded/day $\rangle$

Treatment

Aerobic

$25^{\circ} \mathrm{C}$

0.14 nutrient supplement

$1.02 \quad 91 \% \mathrm{H}_{2} \mathrm{O}$

$0.0 \quad 1 \% \mathrm{H}_{2} \mathrm{O}$

0.001 brine

$70^{\circ} \mathrm{C}$

0.0 nutrient supplement

$0.0 \quad 91 \% \mathrm{H}_{2} \mathrm{O}$

$0.11 \quad 1 \% \mathrm{H}_{2} \mathrm{O}$

0.08 brine

Anaerobic

$25^{\circ} \mathrm{C}$

0.3 nutrient supplement

$0.0 \quad 91 \% \mathrm{H}_{2} \mathrm{O}$

$0.0 \quad 1 \% \mathrm{H}_{2} \mathrm{O}$

0.005 brine

$$
70^{\circ} \mathrm{C}
$$

0.01 nutrient supplement

$0.0 \quad 91 \% \mathrm{H}_{2} \mathrm{O}$

$0.0 \quad 1 \% \mathrm{H}_{2} \mathrm{O}$

0.0 brine
EUROPIUM-EDTA CHELATE DEGRADATION (NET RATES AFTER SUBTRACTION OF STERILE CONTROLS)

\begin{tabular}{c} 
Rate \\
(\% degraded/day) \\
\hline
\end{tabular}

Aerobic

\begin{tabular}{|c|c|}
\hline \multirow[b]{2}{*}{$\begin{array}{l}0.01 \\
0.003 \\
0.001 \\
\cdots\end{array}$} & $25^{\circ} \mathrm{C}$ \\
\hline & $\begin{array}{l}\text { nutrient supplement } \\
91 \% \mathrm{H}_{2} \mathrm{O} \\
1 \% \mathrm{H}_{2} \mathrm{O} \\
\text { brine }\end{array}$ \\
\hline \multirow{3}{*}{$\begin{array}{l}0.0 \\
0.0 \\
0.01 \\
\cdots\end{array}$} & $70^{\circ} \mathrm{C}$ \\
\hline & $\begin{array}{l}\text { nutrient supplement } \\
91 \% \mathrm{H}_{2} \mathrm{O} \\
1 \% \mathrm{H}_{2} \mathrm{O} \\
\text { brine }\end{array}$ \\
\hline & Anaerobic \\
\hline \multirow{3}{*}{$\begin{array}{l}0.2 \\
-- \\
0.0 \\
0.0\end{array}$} & $25^{\circ} \mathrm{C}$ \\
\hline & $\begin{array}{l}\text { nutrient supplement } \\
91 \% \mathrm{H}_{2} \mathrm{O} \\
1 \% \mathrm{H}_{2} \mathrm{O} \\
\text { brine }\end{array}$ \\
\hline & $70^{\circ} \mathrm{C}$ \\
\hline $\begin{array}{l}0.005 \\
\cdots \\
0.01 \\
0.0\end{array}$ & $\begin{array}{l}\text { nutrient supplement } \\
91 \% \mathrm{H}_{2} \mathrm{O} \\
1 \% \mathrm{H}_{2} \mathrm{O} \\
\text { brine }\end{array}$ \\
\hline
\end{tabular}


TABLE XIV

EUROPIUM-CITRATE CHELATE

DEGRADATION (NET RATES AFTER SUBTRACTION OF

STERILE CONTROLS)

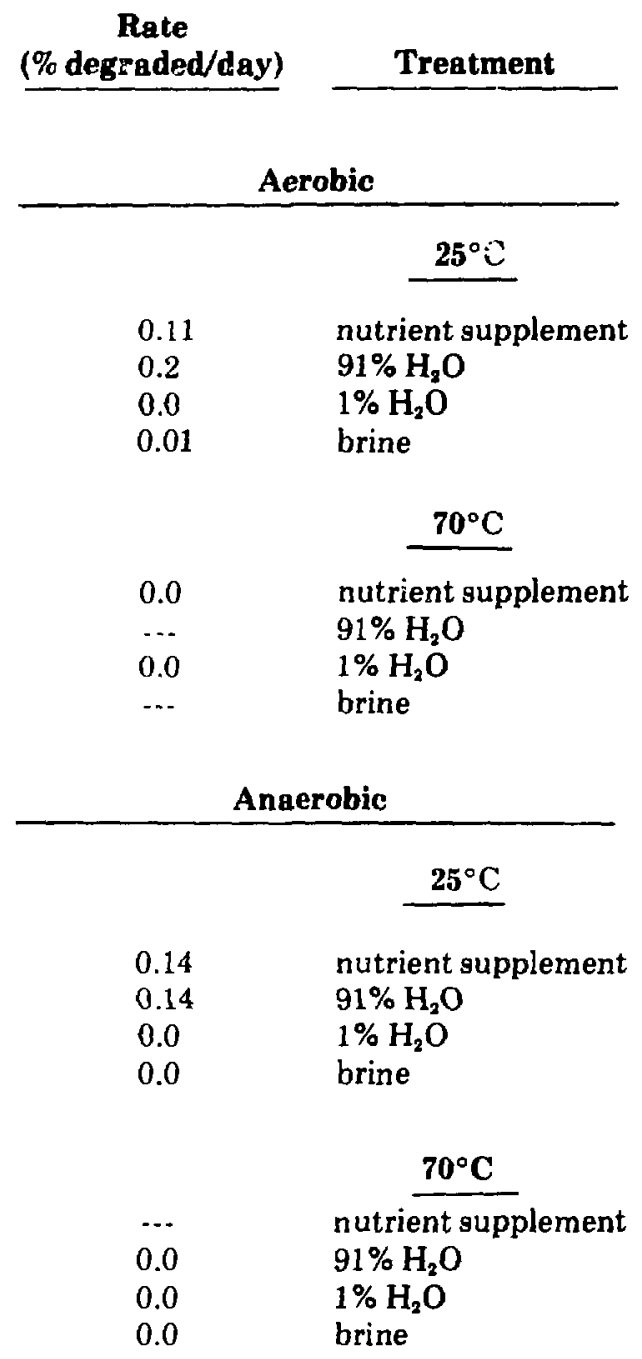




\section{MILESTONES FOH THE MICROBIOLOGICAL STUDIES (WIPP R\&D PROGRAM) BY QUARTERS (LAISL-UNM)}

Quarterly reports

Annual reports

Literature search and update

Capital equipment ordered

Laboratory expendables ordered

Enumeration and identification

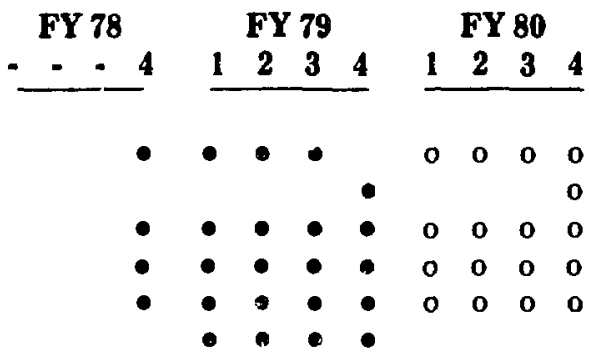
of microflora in LASL TRU burial site soil (LASL)

Fnumeration and identification of microflora in metallic and wood I.ASL TRU waste containers (LASL)

Identification of saltbed microllora

Microbial gas generation (UNM)

Abiotic reactions (LASL)

Alkylation of heavy metals and actinides

Chelation of heavy metals and actinides

Microbial degradation of chelates (iJNM)

Microbial interaction with radionuclides (LASL-UNM)

Alkylr.tion/Volatilization Chelation Solubilization

Chelate degradation

Plate counts

Gas generation

Effect of $\mathrm{PuO}_{2}$ on microbial activity (LASL, UNM) gas generation Gas viability of microoganisms

Effect of microbial activity on the oxidation state of plutonium

Analysis and interpretation of data ${ }^{a}$ (LASL, UNM)

Conclusions and recom. mendations
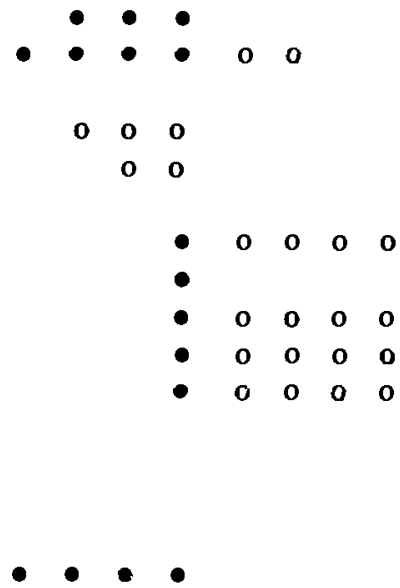

- On schedule oPlanned

The ongoing work may identify additional topics of research that may be included, and other experiments may be deleted by mutual consent of primary investigator and WIPP technical program managers. 


\section{REFERENCES}

1. M. A. Molecke, "WIPP TRU Waste Experimental Characterization Program: Executive Summary," Sandia Laboratories report SAND-78. 1356 (November 1978).

2. P. Colombo, A. J. Weiss, and A. J. Francis, "Evaluation of Isotope Migration-Land Burial Water Chemistry at Commercially Operated Low Level Radioactive Waste Disposal Sites," Brookhaven National Laboretory report BNL. NUREG-50861 (October-December 1977).

3. F. H. F. Au, "The Role of Microorganisms in the Movement of Plutonium," in "The Dynamics of Plutonium in Desert Environments," Nevada Applied Ecology Group Progress Report NVO142 (1974).

4. F. H. F. Au and W. F. Beckert, "Influence of Selected Variables on Transport of Plutonium to Spores of Aspergillus niger," in "The Radiocology of Plutonium and Other Transuranics in Desert Environments," Nevada Applied Ecology Croup Progress Report NVO-153 (June 1975).

5. F. E. Clark, "Agar Plate Method for Total Microbial Count," in Methods of Soil Analysis, Part 2 (Am. Soc. Agron., Madison, 1965) 14601467.

6. M. Alexander, "Most-Probable-Number Method for Microbial Populations," in Methods of Soil Analysis, Part 2 (Am. Soc. Agron., Madison, 1965) 1467-1472.

7. B. J. Barnhart, E. W. Campbell, J. M. Hardin, E. Martinez, D. E. Caldwell, and R. Hallett, "Potential Microbial Impact on Transuranic Wastes Under Conditions Expected in the Waste Isolation Pilot Plant (WIPP), October 1. December 15, 1978," Los Alamos Scientific Laboratory report LA-7788-PR (May 1979).

8. B. J. Barnhart, E. W. Campbell, J. M. Hardin, E. Martinez, D. E. Caldwell, and R. Hallett,
"Potential Microbial Impact on Transuránic Wastes Under Conditions Expected in the Waste Isolation Pilot Plant (WIPP), December 15, 1978-March 15, 1979," Los Alamos Scientific Laboratory report LA-7839-PR (eluly 1979).

9. B. J. Barnhart, E. W. Campbell, E. Martinez, D. E. Caldwell, and R. Hallett, "Potentia! Microbial Impact on Transuranic Wastes Under Conditions Expected in the Waste isolation Pilot Plant (WIPP), March 15-June 15, 1979," Los Alamos Scientific Laboratory report LA7918-PR (July 1979).

10. J. J. Licciardello, J. T. R. Nickerson, S. A. Goldblith, C. A. Shannon, and W. W. Bishop, "Development of Radiation Resistance in Salmonella Culıures," Appl. Microbiol. 18, 24-30 (1969).

11. T. Hoshinaka, K. Yano, and H. Yamaguchi, "Isolation of Highly Radioresistant Bacterium Arthrobacter Radiotolerans, nov. sp.," Agric. Biol. Chem. 37, 2269-2275 (1973).

12. A. Jernelov and A. L. Martin, "Ecological Implications of Metal Metabolism by Microorganisms," Swedish Water and Air Pollution Research Laboratory, Drottning Kristinas Vag 47 D, S-114-28, Stockholm, Sweden, publication B-233:1-21 (1975).

13. I. J. Higgius and R. G. Burns, The Chemistry and Micrabiology of Pollution (Academic Press, New York, 1975), 202-206.

14. N. Irmura, E. Sakegawa, S. K. Pan, K. Nagao, J. Y. Kim, T. Kwan, and T. Vkita, "Chemical Methylation of Inorganic Mercury with Methylcobalamin, a Vitamin $B_{12}$ Analog," Science 172, 1248-1249 (1971).

15. R. W. Fleming and $M$. Alexander, "Dimethylselenide and Dimethyltelluride Formation by a Strain of Penicillium," Appl. Microbiol. 24, 424-429 (1972). 
16. J. M. Cleveland, The Chemistry of Plutonium (Gordon and Breach Science Publishers, New York, 1979).

17. D. Cohen, "The Absorption Spectra of Plutonium Ions in Perchloric Acid Solut:ons," J. Inorg. Chem. 18, 211-218 (1961).

18. T. J. Marks and A. M. Seyam, "Observations on the Thermal Decomposition of Some Uranium (IV) Tetraalkyls," J. Organomet. Chem. 67, 6166 (1974).

19. $\Gamma$. J. Marks, "Actinide Organometaiiic Chemistry," Acc. Chem. Res. 9, 223-230 (1976).

20. N. M. Ely and M. Tsutsui, "Organolanthanides and Organoactinides, XV. Synthesis and Properties of New $\sigma$-Bonded Organolanthanide Complexes," Inorg. Chem. 14, 2680-2687 (1975).

21. T. Emery, "Hydroxamic Acids of Natural Origin," in Advanced Enzymology (Academic Press, New York, 1971) 135-185.
22. C. E. Lankford, "Bacterial Assimilation of Iron," in CRC Crit. Rev. Microbiol. (Chemical Rubber Co., Cleveland, Ohio, 1973) 273-331.

23. Von Bickel, R. Bosshardt, E. Geumann, P. Reusser, E. Vischer, W. Voser, A. Wettstein, and $H$. Zahner, "Uber die Isolierung and Charakterisierung der Ferrioxamine A-F, neuer Wuchsstoffe der Sideramin-Gruppe," Helv. Chim. Acta XLIII, 2118-2128 (1960).

24. D. E. Caldwell, "Microbial Biogeochemistry of WIPP Wastes," University of New Mexico, Quarterly Report to Sandia Laboratories, June 1-30, 1978, unpublished.

25. T. D. Brock and K. O'Rea, "Amorphous Ferrous Sulfide as a Reducing Agent for Culture of Anaerobes," Appl. Environ. Microbiol. 33, 254256 (1977).

26. M. A. Molecke, "Gas Generation from Transuranic Waste: An Interim Assessment," Sandia Laboratories report SAND-79-0117 (January 1979)(draft).

27. J. D. A. Miller, Microbial Aspects of Metallurgy (American Elsevier Publishing Co., 1970). 


\section{Distribution}

US Department of Energy, Leadquarters

Office of Nuclear Waste Manageinent

Washingt on, DC 20545

Eugenr: F. Beckett, Project Coordinator (WIPP) (1)

Colin A. Heath, Director, Division of Waste Isolation (2)

Sheldun Meyurs

Raymond G. Romatowski

R. Stcin

US Department of Energy, Albuquerque Operations

P.O. Box 5400

Albuquergue, NM 87185

D. T. Sclucler, Manager, WIPP Project Office (2)

G. Dennis, Dircetor, Public Affairs Division

S. C. Taylor, C\&Tl Division (for Public Reading Rooms)

US Department of Energy

Carlsbad WIPP Project Office

Roon 113, Federal Building

Carlsbad, NM 88220

US Department of Finergy

c/o Battelle

Office of Nuclear Waste Isolation

505 King Avenue

Columbus, OHI 43201

Jefi O. Neft

Battelle Memorial Institute

Oftice of Nuclear Waste Isolation

505 King Avenue

Columbus, OH 43201

Neil Carter, General Manager

R. Heineman

Wayne Carbiener

P. Hoffman

J. F. Kircher

D. Moak

ONWl Library

Westinghouse Electric Corporation P.O. Box 40039

Albuquerque, NM 87196

R. C. Mairson

D. Hulbert

V. li. Likar

H. H. Irby

Hobbs Public Library

509 N. Ship St.

Hobbs, NM 88248

Ms. Marcia Lewis, Librarian

Lokesh Chaturvedi

Department of Civil Engineering

Box 3E

New Mexico State University

Las Cruces, NM 88003

Bechtel Inc.

P.O. Box 3965

San Francisco, CA 94119

R. A. Langley
National Acadenyy of Sciences, WIPP Panel

Frank L. Parker, Chairman

Department of Environmental and Water Resources Engineering

Vanderbilt University

Nashville, TN 37235

Konrad B. Krauskopf, Vice Chairman

Departinent of Geology

Stanford University

Stanford, CA 94305

Dr. Karl P. Cohen, Member

928 N. California Avenue

Palo Alto, CA 94303

Neville G. W. Cook, Member

Department of Matcrial Sciences and Engineering

University of California at Berkeley

Heart Mining Building, No. 320

Berkelcy, CA 94720

Merril Eisenbud, Member

Inst. of Environmental Medicine

New York University Medical Center

Box 817

Tuxedo, NY 10587

Fred M. Ernsberger, Member

Glass Research Center

PPG Indust rics, Inc.

Box 11472

Pit1sburgh, PA 15238

Roger Kasperson, Member

Center for Technology, linvironment and Development

Clark University

Worcester, MA 01610

Richard R. Parizek, Member

Department of Hydrogeology

Pennsylvania State University

University Park, PA 16802

Thomas H. Pigford, Member

Department of Nuclear Engineering

Unjversity of California

Berkeley, CA 94720

Roger W. Stachle, Member

Dean, Institute of Technology

University of Minnesota

Lind Ilall

Minneapolis, MN 55455

Jolın W. Winchester, Member

Department of Oceanography

Florida State Unjucrsity

Tallahassec, I:L 32306

D'Arcy A. Shock

233 Virginia

Ponca City, OK 74601

National Acadenyy of Sciences

Committee on Radioactive Waste Management

2101 Constitution Avenuc, NW

Washington, DC 20418

John T. Holloway (2) 
WIPP Public Reading Room

Atomic Muscum, Kirtland liast Al'B

Albuquerque, NM 87185

Attn: Ms. Gwynn Schreiner

WIPP Publi: Reading Room

Carlsbad Municipal Library

101 S. Hallagueno St.

Carlsbad, NM 88220

Attn: Lee llubbard, Head Librarian

Thomlas Bramnigan Library

106 W. Hadley St.

Las Cruces, NM 88001

Attr: Don Dresp, llead Librarian

Roswell Public Library

301 N. Pennsylvanja Avenue

Rosivall, NM 88201

Attn: Ms. Nancy Langston

Dr. Bruno (;ilctti

Department of Geological Sciences

Brown University

Providence, RI 02912

Dr. Kaymond Siever

Department of Geological Sciences

llarvard University

Cimbridue. MA 02138

Dr. John Ilandin

Center of Tectonophysics

Texas A \& $M$ Unjversity

College Station, TX 77840

Dr. John Lyons

Department of Farth Sciences

Darmouth College

Hanover, NH 03755

Dr. George Pinder

Department of Civil Fngincering

Princeton University

Princeton, NJ 08540

New Mexico Advisory Com hittec on WIPP

NMIMT Graduate Ofince

Socorro, NM 87801

Marvin H. Wilkening, Chairman (2)

State ol New Mexico

Envirommental Ivaluation Group

320 Marcy Strect

P.O. Box 968

Santa l:, NM 87503

Robert H. Neill, Dircetor (2)

NM Departmen of Inergy \& Minerals

P.O. Box 2770

Santa Fe, NM 87501

Larry Kehoc, Secretary

Kasey LaPlante, Librarian

J. E. Magruder,

Sandia Carlsbad Representative

401 North Canal Street

Carlsbad. NM 88220

\section{John Gervers}

Coordinator, Governor's Task l:orce for WIPP

State Capitol, Roon 247

San a Fe, NM 87503

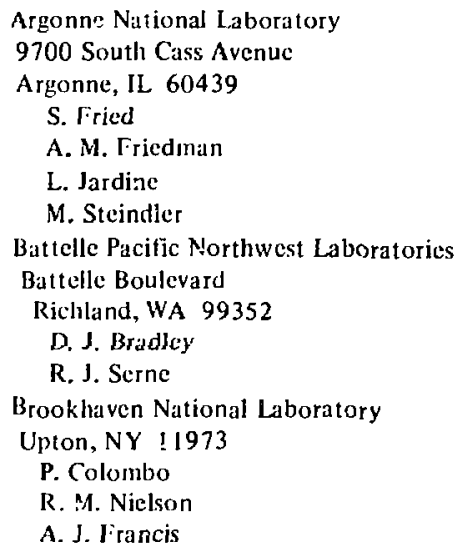

li. I. DuPont de Ncmours \& Company

Savannal River Laboratory

Aiken, SC 29801

E. L. Albenisius

N. L. Bibler

J. R. Wilcy

R. F. Gerton

US Department of linergy

Richland Operations Office

Nuclear Fucl Cycle \& Production Division

P.O. Box 500

Richland, WA 99352

Institut fur Ticflagerung

Theodor-Heuss Strasse 4

D-3300 Braunschweig

ILEDI:RAL REPUBLIC OF GERMANY

K. Kuhn

P. Uermmann

D. E. Large

US Department of Energy

Research \& Technical Support Division P.O. Box E

Oak Ridge, TN 37830

Los Alamos Scicntific Laboratory

Los Alamos, NM 87545

T. K. Keenan, H-7

D. I. Petersen, LS-DO

G. R. Waterbury, CMB-1

A. Zerwekh, CMB-1

S. Kosiewicz, CMB-1

Oak Ridgc National Laboratory

Box Y

Oak Ridge, TN 37830

Attn: R. E. Blanko

L. R. Dole

J. G. Moore

Oak Ridge National Laboratory

Box $X$

Environmental Sciences Division

Oak Ridge, TN 37830

Richard Streher

The Pennslyvania State University

Materials Research Laboratory

Unjversity Park, PA 16802

Rustum Roy 


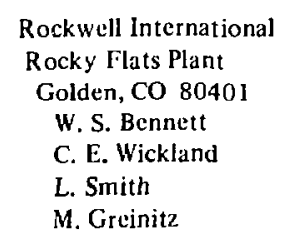

Svensk Karnbransleforsorjning $A B$

Project KBS

Karnbranslesakerhet

Box 5864

10248 Stockholm, SWEDEN

Fred Karlsson

US Department of Energy

Division of Waste Products

Mail Stop B-107

Washington, DC 20545

G. H. Daly

J, E. Disckhoner

US Department of Iinergy

Id aho Operations Office

Nuclear Fuel Cycle Division

550 Second Street

Idaho Falls, ID 83401

R. M. Nelson

J. Whitsctt

US Department of Inergy

Suvannah River Operations Office Waste Management Project Office

P.O. Box A

Aiken, SC 29801

J. R. Covell

D. Fulmer

University of New Mexico

Biology Department

Albuquerquc, NM 87131

D. E. Caldwell (10)
New Mexico Institute of Mining and Technology

Department of Biology

Socorro, NM 87801

J. A. Brierley

C. E. Zobe:I, A-002

Scripps Institute of Oceanography

University of California, San Diego

La Jolla, CA 92093

Sandia Internad:

3141 T. L. Werner (5)

3151 W. L. Garner, for DOE/ TIC (Unlimited Releasc) (3)

3154-3 R. P. Campbell, for DOE/TIC ( 25)

4413 N. R. Ortiz

4500 E. H. Beckner

4510 W. D. Weart

4511 G. E. Barr

4511 S. J. Lambert

4512 T. O. Hunter

4512 D. R. Fortney

4512 M. A. Molecke (10)

4514 S. Neuhauser

4530 R. W. Lynch

4537 L. D. Tyler

4538 R. C. Lincoln

4540 M. L. Kramm

4542 Sandia WIPP Central I:iles (2) (TRU)

5812 C.J. Northrup

5812 E. J. Nowak

5840 N. J. Magnani

5841 D. W. Schaefer

8266 E. A. Aas (2) 